\title{
PENGARUH BUAH TOMAT (SOLANUM LYCOPERSICUM) TERHADAP PENINGKATAN NAFSU MAKAN TIKUS PUTIH (RATUS NORVEGICUS STAIN WISTAR)
}

\author{
${ }^{1}$ Eko Sari Ajiningtyas, AMK., SST., M. Kes. ${ }^{2}$ Christiani Mutiara Hilda ${ }^{3}$ Lala Aruna* \\ STiKes Borneo Cendekia Medika Pangkalan Bun \\ ${ }^{1}$ Email : mahardikagunardi@gmail.com² cristina@gmail.com ${ }^{3}$ lala@gmail.com
}

\begin{abstract}
ABSTRAK
Masalah kesehatan dijumpai di kalangan anak prasekolah/TK adalah berkurangnya nafsu makan anak makin meningkat. Makanan yang disuguhkan ibu harus mengandung unsur nutrisi serta sejumlah vitamin, mineral, dan serat seperti buah tomat. Tujuan penelitian ini untuk menganalisis pengaruh jus buah tomat terhadap peningkatan nafsu makan pada tikus putih (Ratus Novergicus Stain Wistar).

Desain penelitian adalah true eksperimental dengan pendekatan metode pretest-posttest with control group. Populasinya tikus putih (ratus novergicus stain wistar), dengan sampel 20 tikus, tekhnik purposive sampling. Pengumpulan data dengan observasi.

Hasil penelitian pada kelompok kontrol peningkatan berat badan rata-rata $0,12 \mathrm{gr}-0,37 \mathrm{gr}$ dan porsi makan rata-rata $0,04 \mathrm{gr}-0,86$ gr. Sedangkan pada kelompok perlakuan peningkatan berat badan rata-rata $0,63 \mathrm{gr}-5,33 \mathrm{gr}$ dan peningkatan porsi makan rata-rata $0,04 \mathrm{gr}-3,14 \mathrm{gr}$.

Analisis Uji Uji T sampel beerpasangan didapatkan hasil nilai sig (2-tailed) $\rho: 0,000$ dan $\alpha$ : 0,05 , jadi $\rho<\alpha$ sehingga $\mathrm{H}_{0}$ ditolak dan $\mathrm{H}_{1}$ diterima, artinya ada pengaruh buah tomat (solanum lycopersicum) terhadap nafsu makan tikus putih (ratus novergicus stain wistar), dengan kekuatan pengaruh $95 \%$ dan arah pengaruh positif.

Masyarakat yang mempunyai anak usia pra sekolah untuk memberikan buah tomat setiap hari dengan tujuan meningkatkan nafsu makan anak sehingga tumbuh kembang anak dapat berkembang dengan baik.
\end{abstract}

Kata kunci : Buah Tomat, Nafsu Makan

\section{EFFECT OF FRUIT TOMATO (SOLANUM LYCOPERSICUM) THE INCREASE APPETITE OF WHITE RATS (RATUS NORVEGICUS STAIN WISTAR)}

\begin{abstract}
Common health problems among in kindergarten was the decline of appetite child was further increased. The food was served mothers should contain a number of nutrients as well as vitamins, minerals, and fiber such as tomatoes. For the purpose of this study to analyze the effect of fruit tomato to increase appetite in rats (Ratus Norvegicus Stain Wistar).

The study design was a true experimental method approach pretest-posttest with control group. The population of white rats (ratus norvegicus stain wistar), with a sample of 20 rats, purposive sampling techniques. Collecting data through observation.

Results of the study in the control group weight gain average of $0.12 \mathrm{gr}-0.37 \mathrm{gr}$ and eating an average of $0.04 \mathrm{~g}-0.86 \mathrm{~g}$. Whereas in the treatment group weight gain average of $0.63 \mathrm{~g}-5.33$ $\mathrm{g}$ and increase the average size of the meal GR-0.04 $3.14 \mathrm{gr}$.
\end{abstract}


Data analysis showed sig (2-tailed) $\rho: 0,000$ and $\alpha: 0.05$, so $\rho<\alpha$ so $H 0$ was rejected and $H 1$ accepted, meaning that there was the influence of tomato (Solanum lycopersicum) on appetite rats (ratus norvegicus stain wistar), with the strength of the effect of $95 \%$ and a positive influence direction.

People who have pre-school age children to give tomatoes every day with the aim of improving the child's appetite so the development of the child can develop properly.

Keywords: Fruit Tomato, Appetite

\section{PENDAHULUAN}

Indonesia telah berhasil menurunkan tingkat kemiskinan, sebagaimana diukur oleh indikator USD 1,00 per kapita perhari, menjadi setengahnya. Kemajuan tingkat kemiskinan belum tercapai secara maksimal dalam upaya untuk lebih menurunkan lagi tingkat kemiskinan, sebagaimana diukur oleh garis kemiskinan nasional dan dari tingkat saat ini sebesar 13,33 persen (2010) menuju targetnya 8 10 persen pada tahun 2014. Kemiskinan sangat erat kaitannya dengan kekurangan gizi pada balita, hal ini berhubungan dengan konsumsi makanan yang didapat dari orangtua. Kekuarangan gizi pada balita bisa juga disebabkan oleh orang tua yang tidak perhatian ataupun ibu terlalu sibuk bekerja dan asupan makanan diserahkan kepada pengasuh sehingga gizi anak tidak terkontrol. Anak usia TK merupakan masa tumbuh kembang yang relatif pesat. Berbagai masalah kesehatan dijumpai di kalangan anak prasekolah/TK, diantaranya adalah kurangnya pertumbuhan fisik secara optimal. Kesulitan makan merupakan suatu gejala dari berbagai penyakit atau gangguan fungsi tubuh, bukan merupakan suatu bentuk diagnosis atau penyakit tersendiri. Gangguan nafsu makan umumnya dialami anak usia 4-6 tahun (Santoso, 2012). Berkurangnya nafsu makan anak makin meningkat berkaitan dengan makin meningkatnya interaksi dengan lingkungan, mereka lebih mudah terkena penyakit terutama penyakit infeksi baik yang akut maupun yang menahun, infeksi cacing dan sebagainya. Pada usia 4-5 tahun berkurangnya nafsu makan di samping karena sakit juga oleh karena faktor lain misalnya waktu/kesempatan untuk makan karena kesibukan belajar atau bermain (Sunarjo, 2013).

Data UNICEF pada tahun 2013 diperkirakan nafsu makan anak yang kurang dapat menyebabkan lebih dari 21,6 juta anak mengalami gizi kurang dan 216.510 mengalami gizi buruk. Insidensi lebih dari 100/100.000 penduduk per tahun terjadi di wilayah Asia Selatan, Asia Tengah, Asia Tenggara dan di wilayah bagian selatan Afrika, dari jumlah tersebut $70-80 \%$ kasus terjadi di ASIA (WHO, 2013). Data RISKESDAS 2013 di Indonesia gizi buruk $5,7 \%$, gizi kurang $13,9 \%$, sedangkan di Jawa Timur sebanyak $40,6 \%$ penduduk mengkonsumsi makanan di bawah $70 \%$ dari Angka Kecukupan Gizi (AKG) yang dianjurkan tahun 2014. Keadaan ini banyak dijumpai pada anak usia sekolah $(41,2 \%)$, remaja $(54,5 \%)$, dan ibu hamil $(44,2 \%)$ (Riskesdas, 2013). Menurut data dari Dinas Kesehatan Kabupaten Kediri yang mengalami gizi buruk pada tahun 2013 sebanyak $5,49 \%$ dari balita yang ada. Sedangkan, berdasarkan penimbangan balita yang dilakukan selama tahun 2014, terdapat balita di bawah garis merah sebanyak 5,70\% (Dinkes Kab. Kediri, 2013). Berdasarkan studi pendahuluan yang dilakukan pada tanggal 10 Desember 2014 di TK Dharma Wanita Plaosan II Kecamatan Wates Kabupaten Kediri dengan melakukan wawancara pada 10 orang tua anak diketahui bahwa ada 8 anak (80\%) mengalami nafsu makan berkurang, 1 anak (10\%) memiliki nafsu makan yang berubahubah terkadang meningkat terkadang menurun dan 1 anak (10\%) memiliki nafsu makan yang baik. Dari 8 anak yang mengalami nafsu makan berkurang 
dikarenakan anak sakit, kesibukan bermain pada anak yang masih usia pra sekoah.

Secara umum faktor yang merupakan penyebab kesulitan makan dapat dibedakan menjadi 3 kelompok diantaranya, faktor nutrisi, faktor penyakit / kelainan organic dan faktor gangguan / kelainan psikologis. Pengaruh hilang atau berkurangnya nafsu makan tampaknya merupakan penyebab utama masalah kesulitan makan pada anak. Pengaruh nafsu makan ini bisa mulai dari yang ringan (berkurang nafsu makan) hingga berat (tidak ada nafsu makan). Tampilan gangguan nafsu makan pada anak diantaranya menolak makanan yang diberikan, mengulur waktu saat makan, memilih-milih makanan. Pada kesulitan makan yang berat dan berlangsung lama akan berdampak pada kesehatan dan tumbuh kembang anak. Jika berkepanjangan akan berdampak gangguan kesehatan dan perkembangan anak. Selain itu nafsu makan erat kaitanya dengan berat badan. Kebanyakan penderita gangguan nafsu makan juga diikuti dengan penurunan berat badan yang cukup drastis sehingga memiliki berat badan dibawah normal. Ketidakidealan berat badan dapat menyebabkan berbagai masalah dan mengancam jiwa anak-anak. Gangguan ini sukar diatasi selain itu sukar untuk didiagosa penyebabnya, juga tidak ada obat konvensional untuk meningkatkan nafsu makan melainkan hanya efek dari obat tersebut. Gangguan nafsu makan dapat menimbulkan sebuah gejala tergantung dari jenis dan jumlah zat gizi yang kurang. Bila anak hanya tidak menyukai makanan tertentu misalnya buah atau sayur akan terjadi defisiensi vitamin A. Bila hanya mau minum susu saja akan terjadi anemi defisiensi besi. Bila kekurangan kalori dan protein akan terjadi Kekurangan Energi Protein (KEP) (Gunarso, 2011: 72).

Program pemerintah yang dilakukan dengan pemeriksaan fisik, bahkan mungkin diperlukan pemeriksaan penunjang. Pada keadaan yang berat mungkin penyebabnya tidak hanya satu faktor (multi faktorial) selain itu dilakukan pemberian vitamin B 12 dan peningkatan gizi tambahan pada anak saat jadwal posyandu. Mengoreksi keadaan defisiensi gizi yang ditemukan. Sedapat mungkin diberikan dalam bentuk makanan, bila tidak mungkin baru diberikan dalam bentuk obat-obatan (Widodo, 2013). Selain itu sebaiknya makanan yang disuguhkan ibu di rumah mengandung unsur nutrisi serta sejumlah vitamin, mineral, dan serat seperti buah tomat. Pemberian jus tomat 1 jam sebelum makan diharapkan dapat dilakukan setiap hari untuk meningkatkan nafsu makan anak karena dalam buah tomat banyak kandungan zat yang dapat meningkatkan nafsu makan. Selain itu jus tomat juga terasa segar dan disukai oleh anak-anak.

Tomat mengandung alkaloid slonain $(0,007 \%)$, saponin, asam folat, asam malat, asam sitrat, bioflavonoid, protein, lemak, gula (glukosa dan fruktosa), adenine, trigonelin, kholin, tomatin, mineral $(\mathrm{Ca}, \mathrm{Mg}$, $\mathrm{P}, \mathrm{K}, \mathrm{Na}, \mathrm{Fe}$, Sulfur, chlorine), vitamin (B1, B2, B6, C, E, A, Likopen, niasin), karbohidrat, histamine, serat, Zat Fitonutrien. Sari buah tomat mengandung vitamin dan mineral yang cukup lengkap. Dari 100 gram jus tomat akan diperoleh kalsium $7 \mathrm{mg}$, fosfor $15 \mathrm{mg}$,zat besi $0,9 \mathrm{mg}$, natrium $230 \mathrm{mg}$, dan kalium $230 \mathrm{mg}$. Vitamin yang terdapat dalam 100 gram sari buah tomat adalah vitamin A (1.050 IU), vitamin B1 (0.05 mg), vitamin B2 (0,03 mg) dan vitamin $\mathrm{C}(16 \mathrm{mg})$. Tomat memiliki rasa yang sedikit asam membuat selera makan meningkat. Rasa asam buah tomat berasal dari asam sitrat. Berkhasiat menambah nafsu makan dengan cara memperbanyak keluarnya air liur. Berdasarkan penelitian bahan bahan yang dikandung di dalam tomat memiliki manfaat salah satunya untuk meningkatkan nafsu makan. Rasa asam pada tomat berasal dari kandungan asam sitrat menyebabkan tomat terasa segar, sehingga dapat menambah nafsu makan. Tomat kaya garam mineral yang merangsang aliran air liur. Mineral ini berguna merangsang nafsu makan sekaligus membuat makanan mudah dicerna tubuh. Konsumsi tomat teratur 
membantu mengobati penyakit anoreksia (kehilangan nafsu makan). Olahan tomat terbaik adalah berupa jus. Minum Jus tomat satu jam sebelum makan mampu meningkatkan nafsu makan. Tomat tua dan masak alami selalu berbau alkalin dan rasanya sedikit masam, Itu karena tomat memiliki garam mineral. Mineral-mineral itulah yang merangsang aliran air liur, sehingga menambah rasa lapar sekaligus memungkinkan makanan dicerna baik (Dewi, 2012).

Berdasarkan uraian di atas maka peneliti tertarik untuk melakukan penelitian tentang" Pengaruh Buah Tomat (Solanum Lycopersicum) terhadap Peningkatan Nafsu Makan pada Tikus Putih (Ratus Novergicus Stain Wistar) di Laboratorium Farmakologi Universitas Brawijaya Malang”.

\section{Konsep Buah Tomat}

Tomat (Solanum lycopersicum syn. Lycopersicum) adalah tumbuhan dari keluarga Solanaceae, tumbuhan asli Amerika Tengah dan Selatan, dari Meksiko sampai Peru. Tomat merupakan tumbuhan siklus hidup singkat, dapat tumbuh tinggi setinggi 1-3 $\mathrm{m}$. Tomat merupakan keluarga dekat dari kentang (Fakriana, 2014: 62).

$\begin{array}{ll}\begin{array}{l}\text { Kingdom } \\ \text { (Tumbuhan) }\end{array} & : \text { Plantae } \\ \begin{array}{l}\text { Subkingdom } \\ \text { (Tumbuhan Berpembuluh ) }\end{array} & : \text { Tracheobionta } \\ \begin{array}{l}\text { Super Divisi } \\ \text { (Menghasilkan biji) }\end{array} & : \text { Spermatophyta } \\ \begin{array}{l}\text { Divisi } \\ \text { (Tumbuhan berbunga) }\end{array} & \\ \text { Kelas } & : \text { Magnoliophyta } \\ \text { (Berkeping dua/dikotil) } & \\ \text { Sub kelas } & : \text { Asteridae } \\ \begin{array}{l}\text { Ordo } \\ \text { Famili }\end{array} & : \text { Solanales } \\ \text { terong-terongan) } & : \text { Solanaceae (Suku } \\ \text { Genus } & : \text { Solanum }\end{array}$

Tomat adalah buah. Alasannya, ovariumnya bersama dengan bijinya,dan berasal dari tanaman berbunga. Untuk pemanfaatanya, tomat terbagi menjadi 2 jenis yaitu, tomat untuk sayur dan tomat sebagai buah. Buah tomat dapat dimakan langsung, dibuat jus, saus tomat, dimasak (Dewi, 2012: 33).

Didalam tomat terdapat kandungan alkaloid slonain $(0,007 \%)$, saponin, asam folat, asam malat, asam sitrat, bioflavonoid, protein, lemak, gula (glukosa dan fruktosa),adenine, trigonelin, kholin, tomatin, mineral $(\mathrm{Ca}, \mathrm{Mg}$, $\mathrm{P}, \mathrm{K}, \mathrm{Na}, \mathrm{Fe}$, Sulfur, chlorine), vitamin (B1, B2, B6, C, E, A, Likopen, niasin), karbohidrat, histamine, serat, Zat Fitonutrien. Sari buah tomat mengandung vitamin dan mineral yang cukup lengkap. Dari 100 gram jus tomat akan diperoleh kalsium $7 \mathrm{mg}$,fosfor $15 \mathrm{mg}$,zat besi $0,9 \mathrm{mg}$, natrium $230 \mathrm{mg}$, dan kalium $230 \mathrm{mg}$. Vitamin yang terdapat dalam 100 gram sari buah tomat adalah vitamin $\mathrm{A}(1.050 \mathrm{IU})$, vitamin B1 $(0.05 \mathrm{mg})$, vitamin B2 $(0,03 \mathrm{mg})$ dan vitamin $\mathrm{C}$ (16 mg).

Rasa asam dalam buah tomat berasal dari kandungan asam sitrat menyebabkan tomat terasa segar, sehingga dapat menambah nafsu makan. Tomat kaya akan garam mineral yang merangsang aliran air liur. Mineral ini berguna merangsang nafsu makan sekaligus membuat makanan dicerna tubuh,serta menambah rasa lapar sekaligus memungkinkan makanan dicerna dengan baik (Dewi, 2012: 40-42).

\section{Konsep Kesulitan Nafsu Makan}

Dorongan untuk makan dipengaruhi oleh rasa lapar dan nafsu makan. Nafsu makan merupakan suatu keadaan yang mendorong seseorang untuk memuaskan keinginan makan. Nafsu makan diregulasi oleh hipotalamus terutama pada hipotalamus lateral serta nuklei ventro medialis. Rangsangan terhadap hipotalamus lateral akan mengakibatkan meningkatnya nafsu makan sedangkan rangsangan terhadap nuklei ventro medialis akan berefe sebaliknya. 
Gangguan nafsu makan merupakan gangguan klinis yang penting namun sering kali diabaikan (Grilo dan Mitchell, 2010). Masalah ini sebenarnya merupakan hal yang sepele namun sering menjadi masalah utama pada anak-anak (Manikam dan Perman, 2010).

Berat badan yang mencapai dibawah $75 \%$ berat badan normal dapat menyebabkan gangguan perkembangan anak dan osteoporosis dini. Selain itu, sintesi protein fungsional otak juga dapat terganggu dan menyebabkan gangguan otak yang apabila kronik dapat menjadi atrofi pada otak. Apabila gangguan nutrisi ini berlangsung dalam jangka waktu yang panjang maka dapat menyebabkan berbagai masalah kesehatan yang dapat mengancam jiwa anak-anak (Waugh dan Lask, 2010). Bahkan menurut Buddet al. gangguan nafsu makan pada anak tidak hanya berdampak pada kesehatan anak, namun dapat pula berpengaruh terhadap hubungan anak dan orang tuanya. Nafsu makan merupakan keadaan yang mendorong seseorang untuk memuaskan keinginan untuk makan selain rasa lapar. Gangguan nafsu makan merupakan gangguan klinis yang penting namun sering kali diabaikan (Grilo dan Mitchell, 2010).

\section{Konsep Tikus Putih (Ratus Norvegicus Stain Wistar)}

Tikus adalah binatang yang hidup bersama, tinggal di dalam selama cuaca dingin dan bergerak di luar selama musim semi dan musim panas, bentuk-bentuk liar, tinggal di luar sepanjang hidup mereka, dan dikurung binatang, terus untuk penelitian, pengujian, mengajar, hewan peliharaan dan mewah (Isroi, 2010: 23).

$\begin{array}{ll}\text { Kingdom } & : \text { Animalia } \\ \text { Phylum } & : \text { Chordata } \\ \text { Class } & : \text { Mammalia } \\ \text { Order } & : \text { Rodentia } \\ \text { Family } & : \text { Muridae } \\ \text { Subfamily } & : \text { Murinae }\end{array}$

\section{Genus \\ :Mus \\ Subgenus \\ :Mus \\ Species \\ :M. musculus \\ Konsep Pengaruh Buah Tomat terhadap Nafsu Makan}

Tomat (Solanum lycopersicum syn. Lycopersicum) adalah tumbuhan dari keluarga Solanaceae, tumbuhan asli Amerika Tengah dan Selatan, dari Meksiko sampai Peru. Tomat merupakan tumbuhan siklus hidup singkat, dapat tumbuh tinggi setinggi 1-3 $\mathrm{m}$. Tomat merupakan keluarga dekat dari kentang (Fakriana, 2014: 64).

Nafsu makan merupakan keadaan yang mendorong seseorang untuk memuaskan keinginan untuk makan selain rasa lapar. Gangguan nafsu makan merupakan gangguan klinis yang penting namun sering kali diabaikan (Grilo dan Mitchell, 2010: 17).

Berbagai unsur yang terlibat dalam makan yaitu alat pencernaan makanan dari rongga mulut, bibir, gigi geligi, langit-langit, lidah, tenggorokan, sistem syaraf, sistem hormonal, dan enzim-enzim. Maka dari itu bila terdapat kelainan atau penyakit pada unsur organik tersebut pada umumnya akan disertai dengan gangguan atau kesulitan makan. Mengkonsumsi tomat teratur membantu mengobati penyakit anoreksia (kehilangan nafsu makan).

Dalam olahan terbaik yang digunakan mengatasi gangguan nafsu makan dengan mengkonsumsi jus tomat.Untuk Pengobatan, sebaiknya gula diganti dengan madu atau gula batu. Dalam hal pengobatan menggunakan jus sebaiknya hindari penambahan gula. Minum jus tomat 1 jam sebelum makan dapat meningkatkan nafsu makan (Dewi, 2012: 41-43).

Rasa asam dalam buah tomat berasal dari kandungan asam sitrat menyebabkan tomat terasa segar, sehingga dapat menambah nafsu makan. Tomat kaya akan garam 
mineral yang merangsang aliran air liur. Mineral ini berguna merangsang nafsu makan sekaligus membuat makanan dicerna tubuh, serta menambah rasa lapar sekaligus memungkinkan makanan dicerna dengan baik (Dewi, 2012: 40-42).

\section{BAHAN DAN METODE PENELITIAN}

Dalam penelitian ini menggunakan desain penelitian true eksperimental dengan desain pasca test dengan pemilihan karena berupaya mengungkapkan pengaruh buah tomat (Solanum Lycopersicum) terhadap peningkatan nafsu makan pada Tikus Putih (Ratus Novergicus Stain Wistar). Kelompok eksperimental diberi perlakuan sedangkan kelompok kontrol tidak. Pada kedua kelompok diawali dengan pra-tes. Pengukuran hanya dilakukan setelah pemberian perlakuan selesai (Nursalam, 2011). Rancangan dalam penelitian ini menggunakan pretest posttest dengan kelompok kontrol (pretest-posttest with control group) yaitu pengelompokan anggota-anggota kelompok kontrol dan kelompok eksperimen dilakukan secara acak atau random, kemudian dilakukan pretest (01) pada kedua kelompok tersebut dan diikuti intervensi (X) pada kelompok eksperimen. Setelah beberapa waktu dilakukan posttest (02) pada kedua kelompok tersebut.

\begin{tabular}{l|lll}
\cline { 2 - 4 } R (Kel. Eksperimen & 01 & $\mathrm{X}$ & 02 \\
a) & 01 & (a) & 02 \\
R (Kel. Eksperimen & 01 & $\mathrm{X}$ & 02 \\
b) & 01 & (b) & 02 \\
R. (Kel. Eksperimen & & X & \\
c) & & (c) & \\
R. (Kel. Kontrol) & & & \\
\cline { 2 - 3 }
\end{tabular}

Keterangan :

R. (Kel. Eksperimen a) : 5 ekor mencit diberikan dosis $0,5 \mathrm{ml} / \mathrm{ekor} / \mathrm{hari}$

R. (Kel. Eksperimen b) : 5 ekor mencit diberikan dosis $1 \mathrm{ml} / \mathrm{ekor} /$ hari

R. (Kel. Eksperimen c) : 5 ekor mencit diberikan dosis $2 \mathrm{ml} /$ ekor/hari
R. (Kel. Kontrol) : 5 ekor mencit tanpa perlakuan

Besar populasi sebanyak 20 Tikus Putih (Ratus Novergicus Stain Wistar). Sampel adalah sebagian atau wakil populasi yang diteliti (Arikunto, 2011). Dari data tentang populasi di atas akan diseleksi kriteria sampel yang terdiri dari kriteria inklusi. Adapun kriteria inklusi dan eksklusi sebagai berikut :

\section{a. Kriteria Inklusi}

Kriteria inklusi adalah karakteristik umum subyek penelitian dari suatu populasi target yang terjangkau yang akan diteliti (Nursalam, 2011).

Yang termasuk kriteria inklusi dalam penelitian ini adalah :

1. Tikus Putih (Ratus Novergicus Stain Wistar) dengan jenis kelamin jantan

2. Tikus Putih (Ratus Novergicus Stain Wistar) yang mempunyai berat badan 200 - 300 gram

3. Tikus Putih (Ratus Novergicus Stain Wistar) umur 4 bulan atau 12 minggu

4. Tikus Putih (Ratus Novergicus Stain Wistar) dengan keadaan sehat

\section{b. Kriteria Eksklusi}

Kriteria eksklusi adalah menghilangkan atau mengeluarkan subyek yang memenuhi kriteria inklusi dari studi karena berbagai sebab (Nursalam, 2011). Yang termasuk kriteria eksklusi dalam penelitian ini adalah

1. Tikus Putih (Ratus Novergicus Stain Wistar) yang punya penyakit penyerta yang bisa mengganggu pengukuran.

2. Tikus Putih (Ratus Novergicus Stain Wistar) yang cacat fisik.

3. Tikus Putih (Ratus Novergicus Stain Wistar) yang tidak mau makan

4. Tikus Putih (Ratus Novergicus Stain Wistar) yang mati

Dalam penelitian ini besar sampel yang digunakan peneliti adalah 20 ekor tikus 
putih (Ratus Novergicus Stain Wistar) yang terbagi menjadi 2 kelompok yaitu 5 mencit kelompok kontrol dan 15 mencit kelompok perlakuan.

Penelitian ini dalam pengambilan sampel menggunakan cara purposive sampling, yaitu suatu teknik penetapan sampel dengan cara memilih sampel dintara populasi sesuai dengan yang dikehendaki peneliti (tujuan/ masalah dalam penelitian), sehingga sampel tersebut dapat mewakili karakteristik populasi yang telah dikenal sebelumnya (Nursalam, 2014).

\section{Tempat dan Waktu Penelitian}

Penelitian ini rencananya akan dilakukan di Laboratorium Farmakologi SMK BIM Pangkalan Bun. Penelitian ini rencananya akan dilakukan pada bulan Januari sampai April 2016.

\section{HASIL}

Hasil penelitian ini akan dibagi menjadi 2 bagian yaitu data umum dan data khusus. Data umum meliputi karakteristik sampel yang meliputi berat badan sebelum perlakuan dan pembagian kelompok sampel. Sedangkan data khusus meliputi pengaruh buah tomat (solanum lycopersicum) terhadap berat badan pada tikus putih (ratus novergicus stain wistar).

\section{Data Umum}

Berat Badan Tikus Putih (Ratus Novergicus Stain Wistar)

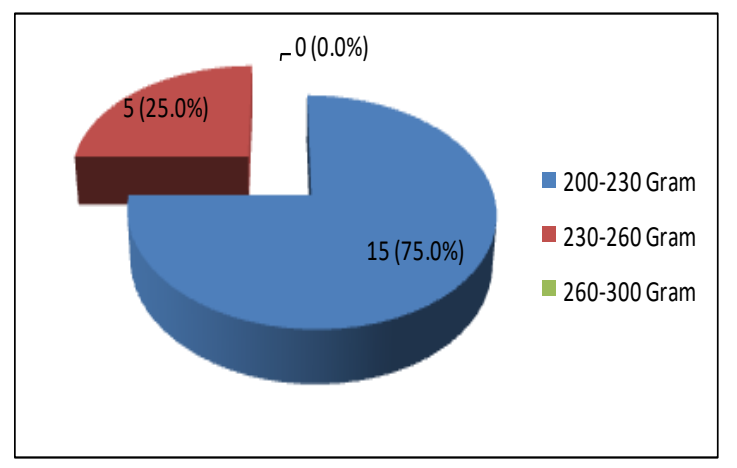

Diagram 1.1 Karakteristik Sampel Berdasarkan Berat Badan Tikus Putih (Ratus Novergicus Stain Wistar) di Laboratorium Farmakologi SMK BIM Pangkalan Bun Tahun 2016

Berdasarkan diagram di atas diketahui bahwa sebagian besar sampel mempunyai berat badan 200-230 Gram sebanyak 15 sampel $(75,0 \%)$.

Kelompok sampel

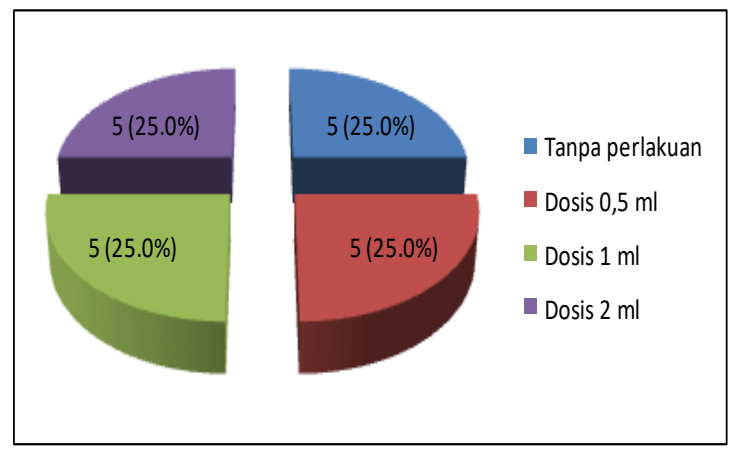

Diagram 1.2 Karakteristik Sampel Berdasarkan Kelompok Sampel di Laboratorium Farmakologi SMK BIM Pangkalan Bun Tahun 2016

Berdasarkan diagram tersebut diketahui bahwa pembagian sampel terbagi menjadi 4 kelompok dimana 5 sampel $(25,0 \%)$ tanpa perlakuan, 5 sampel $(25,0 \%)$ diberikan buah tomat dengan dosis $0,5 \mathrm{ml}, 5$ sampel $(25,0 \%)$ dengan dosis $1 \mathrm{ml}$ dan 5 sampel $(25,0 \%)$ dengan dosis $2 \mathrm{ml}$.

\section{Data Khusus}

\section{Berat Badan Tikus Putih}

\section{a. Berat Badan Tikus Putih pada kelompok kontrol}

Tabel 1.1 Peningkatan Berat Badan Tikus Putih pada Kelompok Kontrol di Laboratorium Farmakologi SMK BIM Pangkalan Bun Tanggal 6 12 Juli 2016

\begin{tabular}{|l|l|l|l|}
\hline Sam & Peningkatan Berat Badan (Gram) & Rata- & Rata- \\
\hline
\end{tabular} 


\begin{tabular}{|c|c|c|c|c|c|c|c|c|c|c|}
\hline \multirow[t]{2}{*}{ pel } & \multicolumn{8}{|c|}{ Hari Ke- } & \multirow{2}{*}{\begin{tabular}{|l|} 
rata \\
BB \\
hari \\
ke-1 \\
sd 7 \\
(gra \\
m) \\
\end{tabular}} & \multirow{2}{*}{\begin{tabular}{|l} 
rata \\
pening \\
katan \\
BB \\
(gram)
\end{tabular}} \\
\hline & 0 & 1 & 2 & 3 & 4 & 5 & 6 & 7 & & \\
\hline 1 & $\begin{array}{l}21 \\
7\end{array}$ & $\begin{array}{l}2 \\
1 \\
7 \\
\end{array}$ & \begin{tabular}{|l|}
21 \\
7
\end{tabular} & $\begin{array}{l}2 \\
1 \\
8 \\
\end{array}$ & $\begin{array}{l}21 \\
8\end{array}$ & $\begin{array}{l}2 \\
1 \\
8\end{array}$ & $\begin{array}{l}2 \\
1 \\
8 \\
\end{array}$ & $\begin{array}{l}2 \\
1 \\
9\end{array}$ & $\begin{array}{c}217 \\
, 86\end{array}$ & 0,12 \\
\hline 2 & $\begin{array}{l}20 \\
6 \\
\end{array}$ & 206 & \begin{tabular}{|l|}
20 \\
6 \\
\end{tabular} & 207 & $\begin{array}{l}20 \\
7 \\
\end{array}$ & 208 & 208 & 209 & $\begin{array}{l}207 \\
29\end{array}$ & 0,18 \\
\hline 3 & \begin{tabular}{l|}
21 \\
6
\end{tabular} & 218 & \begin{tabular}{|l|}
21 \\
8
\end{tabular} & 218 & \begin{tabular}{l|}
21 \\
8
\end{tabular} & 219 & 219 & 219 & $\begin{array}{l}218 \\
43\end{array}$ & 0,35 \\
\hline 4 & \begin{tabular}{|l|}
22 \\
0
\end{tabular} & 221 & \begin{tabular}{|l|}
22 \\
1
\end{tabular} & 222 & \begin{tabular}{|l}
22 \\
2
\end{tabular} & 223 & 234 & 224 & $\begin{array}{l}223 \\
86\end{array}$ & 0,55 \\
\hline 5 & \begin{tabular}{l|}
22 \\
2
\end{tabular} & 222 & \begin{tabular}{|l|}
22 \\
3 \\
\end{tabular} & 223 & \begin{tabular}{|l|}
22 \\
3
\end{tabular} & 226 & 227 & 228 & $\begin{array}{l}224, \\
57\end{array}$ & 0,37 \\
\hline
\end{tabular}

Berdasarkan tabel 1.1 tersebut menunjukkan bahwa 5 tikus putih pada kelompok kontrol mengalami peningkatan berat badan selama 7 hari dengan rata-rata $0,12 \mathrm{gr}-0,37 \mathrm{gr}$.

\section{b. Berat Badan Tikus Putih pada kelompok Perlakuan Dosis 0,5 ml}

Tabel 1.2 Peningkatan Berat Badan Tikus Putih pada Kelompok Perlakuan Dosis 0,5 ml di Laboratorium Farmakologi SMK BIM Pangkalan Bun Tanggal 6 - 12 Juli 2016

\begin{tabular}{|c|c|c|c|c|c|c|c|c|c|c|}
\hline \multirow[b]{3}{*}{$\begin{array}{l}\text { Samp } \\
\text { el }\end{array}$} & \multirow{2}{*}{\multicolumn{8}{|c|}{\begin{tabular}{|l|} 
Peningkatan Berat Badan (Gram) \\
Hari Ke- \\
\end{tabular}}} & \multirow{3}{*}{$\begin{array}{l}\text { Rata- } \\
\text { rata } \\
\text { BB } \\
\text { hari } \\
\text { ke-1 } \\
\text { sd } 7 \\
\text { (gra } \\
\text { m) } \\
\end{array}$} & \multirow[b]{3}{*}{$\begin{array}{l}\text { Rata-rata } \\
\text { peningkat } \\
\text { an BB } \\
\text { (gram) }\end{array}$} \\
\hline & & & & & & & & & & \\
\hline & 0 & 1 & 2 & 3 & 4 & 5 & 6 & 7 & & \\
\hline 1 & $\begin{array}{l}20 \\
7\end{array}$ & $\begin{array}{l}21 \\
0\end{array}$ & $\begin{array}{l}21 \\
8\end{array}$ & $\begin{array}{l}22 \\
4\end{array}$ & $\begin{array}{l}23 \\
1\end{array}$ & \begin{tabular}{|l|}
24 \\
3
\end{tabular} & $\begin{array}{l}24 \\
8\end{array}$ & $\begin{array}{l}25 \\
7\end{array}$ & $\begin{array}{l}223,0 \\
0\end{array}$ & 3,71 \\
\hline 2 & $\begin{array}{l}22 \\
0\end{array}$ & $\begin{array}{l}22 \\
2\end{array}$ & $\begin{array}{l}22 \\
3\end{array}$ & $\begin{array}{l}22 \\
4\end{array}$ & $\begin{array}{l}22 \\
7\end{array}$ & $\begin{array}{l}23 \\
2\end{array}$ & $\begin{array}{l}23 \\
5\end{array}$ & $\begin{array}{l}23 \\
7\end{array}$ & $\begin{array}{l}228,5 \\
7\end{array}$ & 1,22 \\
\hline 3 & $\begin{array}{l}21 \\
2\end{array}$ & $\begin{array}{l}21 \\
3 \\
\end{array}$ & $\begin{array}{l}21 \\
5\end{array}$ & $\begin{array}{l}21 \\
7\end{array}$ & $\begin{array}{l}21 \\
8\end{array}$ & $\begin{array}{l}22 \\
3 \\
\end{array}$ & $\begin{array}{l}22 \\
5\end{array}$ & $\begin{array}{l}22 \\
6\end{array}$ & $\begin{array}{l}222,8 \\
6\end{array}$ & 1,27 \\
\hline 4 & $\begin{array}{l}21 \\
2\end{array}$ & $\begin{array}{l}21 \\
3\end{array}$ & $\begin{array}{l}21 \\
5\end{array}$ & $\begin{array}{l}21 \\
7\end{array}$ & $\begin{array}{l}21 \\
8\end{array}$ & $\begin{array}{l}22 \\
3\end{array}$ & $\begin{array}{l}22 \\
5\end{array}$ & $\begin{array}{l}22 \\
6\end{array}$ & $\begin{array}{l}219,5 \\
7\end{array}$ & 1,08 \\
\hline 5 & $\begin{array}{l}20 \\
5\end{array}$ & $\begin{array}{l}20 \\
8\end{array}$ & $\begin{array}{l}21 \\
0\end{array}$ & $\begin{array}{l}21 \\
9\end{array}$ & $\begin{array}{l}22 \\
1\end{array}$ & $\begin{array}{l}22 \\
9\end{array}$ & $\begin{array}{l}23 \\
4 \\
\end{array}$ & $\begin{array}{l}23 \\
7\end{array}$ & $\begin{array}{l}222,5 \\
7\end{array}$ & 2,51 \\
\hline
\end{tabular}

Berdasarkan tabel di atas menunjukkan bahwa 5 tikus putih pada kelompok perlakuan dengan dosis $0,5 \mathrm{ml}$ mengalami peningkatan berat badan selama 7 hari dengan rata-rata $1,08 \mathrm{gr}-3,71 \mathrm{gr}$.

\section{c. Berat Badan Tikus Putih pada kelompok Perlakuan Dosis 1 ml}

Tabel 1.3 Peningkatan Berat Badan Tikus Putih pada Kelompok Perlakuan Dosis $1 \mathrm{ml}$ di Laboratorium Farmakologi SMK BIM Pangkalan Bun Tanggal 6 - 12 Juli 2016

\begin{tabular}{|c|c|c|c|c|c|c|c|c|c|c|}
\hline \multirow[b]{2}{*}{$\begin{array}{l}\text { Sam } \\
\text { pel }\end{array}$} & \multicolumn{8}{|c|}{$\begin{array}{l}\text { Peningkatan Berat Badan } \\
(\text { Gram })\end{array}$} & \multirow{2}{*}{\begin{tabular}{|l} 
Rat \\
a- \\
rata \\
BB \\
hari \\
ke-1 \\
sd 7 \\
(gra \\
m) \\
\end{tabular}} & \multirow{2}{*}{$\begin{array}{l}\text { Rata- } \\
\text { rata } \\
\text { pening } \\
\text { katan } \\
\text { BB } \\
\text { (gram) }\end{array}$} \\
\hline & 0 & 1 & 2 & 3 & 4 & 5 & 6 & 7 & & \\
\hline 1 & \begin{tabular}{|l|}
23 \\
0
\end{tabular} & $\begin{array}{l}23 \\
2\end{array}$ & $\begin{array}{l}23 \\
6\end{array}$ & \begin{tabular}{|l|}
23 \\
8
\end{tabular} & $\begin{array}{l}24 \\
1\end{array}$ & $\begin{array}{l}24 \\
4\end{array}$ & $\begin{array}{l}24 \\
5\end{array}$ & \begin{tabular}{|l|}
24 \\
6
\end{tabular} & $\begin{array}{l}240 \\
29\end{array}$ & 1,47 \\
\hline 2 & \begin{tabular}{|l|}
23 \\
1 \\
\end{tabular} & \begin{tabular}{|l|}
23 \\
3 \\
\end{tabular} & \begin{tabular}{|l|}
23 \\
4 \\
\end{tabular} & \begin{tabular}{|l|}
23 \\
8 \\
\end{tabular} & \begin{tabular}{|l|}
24 \\
4 \\
\end{tabular} & \begin{tabular}{|l|}
24 \\
6 \\
\end{tabular} & \begin{tabular}{|l|}
25 \\
4 \\
\end{tabular} & \begin{tabular}{|l|}
25 \\
6 \\
\end{tabular} & \begin{tabular}{|l|}
243 \\
57 \\
\end{tabular} & 1,8 \\
\hline 3 & \begin{tabular}{|l|}
22 \\
6
\end{tabular} & $\begin{array}{l}22 \\
8\end{array}$ & \begin{tabular}{l|}
23 \\
0
\end{tabular} & $\begin{array}{l}23 \\
1\end{array}$ & $\begin{array}{l}23 \\
3\end{array}$ & $\begin{array}{l}23 \\
4\end{array}$ & $\begin{array}{l}23 \\
6\end{array}$ & \begin{tabular}{|l|}
23 \\
7
\end{tabular} & $\begin{array}{l}232 \\
71\end{array}$ & 0,96 \\
\hline 4 & \begin{tabular}{|l|}
23 \\
3 \\
\end{tabular} & $\begin{array}{l}23 \\
4\end{array}$ & $\begin{array}{l}23 \\
6\end{array}$ & $\begin{array}{l}23 \\
8\end{array}$ & $\begin{array}{l}24 \\
0\end{array}$ & $\begin{array}{l}24 \\
2\end{array}$ & $\begin{array}{l}24 \\
3\end{array}$ & \begin{tabular}{|l|}
34 \\
5
\end{tabular} & $\begin{array}{l}254, \\
00\end{array}$ & 3,00 \\
\hline 5 & $\begin{array}{l}23 \\
6 \\
\end{array}$ & $\begin{array}{l}23 \\
7\end{array}$ & $\begin{array}{l}23 \\
8\end{array}$ & $\begin{array}{l}23 \\
9\end{array}$ & $\begin{array}{l}24 \\
0\end{array}$ & $\begin{array}{l}24 \\
2\end{array}$ & $\begin{array}{l}24 \\
3\end{array}$ & \begin{tabular}{|l|}
24 \\
4 \\
\end{tabular} & $\begin{array}{l}240 \\
43\end{array}$ & 0,63 \\
\hline
\end{tabular}

Berdasarkan tabel tersebut menunjukkan bahwa 5 tikus putih pada kelompok perlakuan dengan dosis $1 \mathrm{ml}$ mengalami peningkatan berat badan selama 7 hari dengan rata-rata $0,63 \mathrm{gr}-3,00 \mathrm{gr}$.

\section{d. Berat Badan Tikus Putih pada kelompok Perlakuan Dosis 2 ml}

Tabel 1.4 Peningkatan Berat Badan Tikus Putih pada Kelompok Perlakuan Dosis $2 \mathrm{ml}$ di Laboratorium Farmakologi SMK BIM Pangkalan Bun Tanggal 6 - 12 Juli 2016

\begin{tabular}{|c|c|c|c|c|c|c|c|c|c|c|}
\hline \multirow{3}{*}{$\begin{array}{l}\text { Samp } \\
\text { el }\end{array}$} & \multirow{2}{*}{\multicolumn{3}{|c|}{\begin{tabular}{|l} 
Peningkat \\
(Gram)
\end{tabular}}} & & \multicolumn{4}{|c|}{ Berat Badan } & \multirow{3}{*}{\begin{tabular}{|l} 
Rata- \\
rata \\
BB \\
hari \\
ke-1 \\
sd 7 \\
(gra \\
m)
\end{tabular}} & \multirow{3}{*}{$\begin{array}{l}\text { Rata-rata } \\
\text { peningka } \\
\text { tan BB } \\
\text { (gram) }\end{array}$} \\
\hline & & & & & & & & & & \\
\hline & 0 & 1 & 2 & 3 & 4 & 5 & 6 & 7 & & \\
\hline 1 & $\begin{array}{l}24 \\
3\end{array}$ & $\begin{array}{l}24 \\
4\end{array}$ & $\begin{array}{l}24 \\
6\end{array}$ & $\begin{array}{l}24 \\
8\end{array}$ & $\begin{array}{l}25 \\
3\end{array}$ & $\begin{array}{l}25 \\
8\end{array}$ & $\begin{array}{l}25 \\
9\end{array}$ & $\begin{array}{l}26 \\
0\end{array}$ & $\begin{array}{l}252 \\
57\end{array}$ & 1,37 \\
\hline 2 & $\begin{array}{l}24 \\
6 \\
\end{array}$ & $\begin{array}{l}24 \\
8\end{array}$ & $\begin{array}{l}24 \\
9 \\
\end{array}$ & $\begin{array}{l}25 \\
3 \\
\end{array}$ & $\begin{array}{l}25 \\
6 \\
\end{array}$ & $\begin{array}{l}26 \\
0\end{array}$ & $\begin{array}{l}26 \\
4\end{array}$ & $\begin{array}{l}26 \\
9\end{array}$ & $\begin{array}{l}257 \\
00\end{array}$ & 1,57 \\
\hline 3 & 20 & 20 & 20 & 21 & 21 & 21 & 21 & 21 & 211, & 0,80 \\
\hline
\end{tabular}




\begin{tabular}{|l|l|l|l|l|l|l|l|l|l|l|}
\hline & 6 & 8 & 9 & 0 & 1 & 3 & 4 & 6 & 57 & \\
\hline 4 & 21 & 21 & 21 & 22 & 22 & 23 & 23 & 23 & 227, & 2,02 \\
& 3 & 6 & 9 & 3 & 9 & 2 & 5 & 6 & 14 & \\
\hline 5 & 21 & 21 & 22 & 22 & 22 & 22 & 33 & 33 & 254, & 5,33 \\
& 7 & 9 & 1 & 2 & 6 & 8 & 1 & 3 & 29 & \\
\hline
\end{tabular}

Berdasarkan tabel tersebut di atas menunjukkan bahwa 5 tikus putih pada kelompok perlakuan dengan dosis $2 \mathrm{ml}$ mengalami peningkatan berat badan selama 7 hari dengan rata-rata $0,80 \mathrm{gr}-5,33 \mathrm{gr}$.

\section{Porsi Makan Tikus Putih}

\section{a. Porsi Makan Tikus Putih pada kelompok kontrol}

Tabel 1.5 Pengukuran Porsi Makan Tikus Putih pada Kelompok Kontrol di Laboratorium Farmakologi SMK BIM Pangkalan Bun Tanggal 6 - 12 Juli 2016

\begin{tabular}{|c|c|c|c|c|c|c|c|c|c|c|}
\hline \multirow{3}{*}{ Sampel } & \multicolumn{8}{|c|}{$\begin{array}{l}\text { Pengukuran } \\
\text { Makan (Gram) } \\
\text { Selama } 30 \text { Menit } \\
\end{array}$} & \multirow{3}{*}{$\begin{array}{l}\text { Rata- } \\
\text { rata } \\
\text { Porsi } \\
\text { makan } \\
\text { hari } \\
\text { ke-1 sd } \\
7 \\
\text { (gram) }\end{array}$} & \multirow{3}{*}{$\begin{array}{l}\text { Rata-rata } \\
\text { peningkatan } \\
\text { Porsi makan } \\
\text { (gram) }\end{array}$} \\
\hline & \multicolumn{8}{|c|}{ Hari Ke- } & & \\
\hline & 0 & & 2 & 3 & 4 & 5 & 6 & 7 & & \\
\hline 1 & 5 & 5 & 7 & 7 & 8 & 10 & 11 & 14 & 9,00 & 0,57 \\
\hline 2 & 9 & 7 & 8 & 8 & 9 & 10 & 11 & 12 & 9,29 & 0,04 \\
\hline 3 & 4 & 3 & 8 & 9 & 10 & 11 & 11 & 13 & 10,00 & 0,86 \\
\hline 4 & 7 & 3 & 9 & 10 & 12 & 12 & 14 & 17 & 11,71 & 0,67 \\
\hline 5 & 9 & 5 & 7 & 11 & 14 & 15 & 17 & 18 & 12,57 & 0,51 \\
\hline
\end{tabular}

Berdasarkan tabel porsi makan menunjukkan bahwa 5 tikus putih pada kelompok kontrol mengalami peningkatan porsi makan selama 7 hari dengan rata-rata 0,04 gr $-0,86$ gr.

\section{b. Porsi Makan Tikus Putih pada kelompok Perlakuan Dosis 0,5 ml}

Tabel 1.6 Pengukuran Porsi Makan Tikus Putih pada Kelompok Perlakuan Dosis 0,5 ml di Laboratorium Farmakologi SMK BIM Pangkalan Bun Tanggal 6 - 12 Juli 2016

\begin{tabular}{|c|c|c|c|}
\hline \multirow[t]{2}{*}{ Sampel } & $\begin{array}{l}\text { Pengukuran Porsi Ma } \\
\text { (Gram) } \\
\text { Selama } 30 \text { Menit }\end{array}$ & \multirow[t]{2}{*}{$\begin{array}{l}\text { Rata- } \\
\text { rata } \\
\text { Porsi } \\
\text { makan }\end{array}$} & \multirow{2}{*}{$\begin{array}{l}\text { Rata-rata } \\
\text { peningkatan } \\
\text { Porsi } \\
\text { makan }\end{array}$} \\
\hline & Hari & & \\
\hline
\end{tabular}

\begin{tabular}{|c|c|c|c|c|c|c|c|c|c|c|}
\hline & 0 & 1 & 2 & 3 & 4 & 5 & 6 & 7 & $\begin{array}{l}\text { hari } \\
\text { ke-1 } \\
\text { sd } 7 \\
\text { (gram) }\end{array}$ & (gram) \\
\hline 1 & 5 & 15 & 20 & 24 & 26 & 28 & 30 & 35 & 25,43 & 2,92 \\
\hline 2 & 7 & 18 & 19 & 25 & 26 & 28 & 29 & 31 & 25,41 & 2,59 \\
\hline 3 & 8 & 18 & 22 & 24 & 26 & 28 & 29 & 32 & 25,57 & 2,51 \\
\hline 4 & 8 & 19 & 21 & 22 & 23 & 23 & 24 & 26 & 22,57 & 2,08 \\
\hline 5 & 9 & 17 & 23 & 25 & 28 & 30 & 31 & 34 & 26,86 & 2,55 \\
\hline
\end{tabular}

Berdasarkan tabel tersebut di atas menunjukkan bahwa 5 tikus putih pada kelompok perlakuan dengan dosis $0,5 \mathrm{ml}$ mengalami peningkatan porsi makan selama 7 hari dengan rata-rata 2,08 gr - 2,92 gr.

\section{c. Porsi Makan Tikus Putih pada kelompok Perlakuan Dosis 1 ml}

Tabel 1.7 Pengukuran Porsi Makan Tikus Putih pada Kelompok Perlakuan Dosis $1 \mathrm{ml}$ di Laboratorium Farmakologi SMK BIM Pangkalan Bun Tanggal 6 - 12 Juli 2016

\begin{tabular}{|c|c|c|c|c|c|c|c|c|c|c|}
\hline \multirow{2}{*}{ Sampel } & \multicolumn{8}{|c|}{$\begin{array}{l}\text { Pengukuran Porsi Makan } \\
\text { (Gram) } \\
\text { Selama } 30 \text { Menit }\end{array}$} & \multirow{2}{*}{\begin{tabular}{|l|} 
Rata- \\
rata \\
Porsi \\
makan \\
hari ke- \\
$\begin{array}{l}1 \quad \text { sd } 7 \\
\text { (gram) }\end{array}$
\end{tabular}} & \multirow{2}{*}{$\begin{array}{l}\text { Rata-rata } \\
\text { peningkatan } \\
\text { Porsi makan } \\
\text { (gram) }\end{array}$} \\
\hline & 0 & 1 & 2 & 3 & 4 & 5 & 6 & 7 & & \\
\hline 1 & 9 & 16 & 20 & 21 & 22 & 24 & 26 & 27 & 22,29 & 1,90 \\
\hline 2 & 8 & 18 & 21 & 25 & 26 & 29 & 30 & 32 & 25,86 & 2,55 \\
\hline 3 & 6 & 19 & 23 & 24 & 26 & 28 & 29 & 31 & 25,71 & 2,82 \\
\hline 4 & 6 & 21 & 23 & 25 & 27 & 28 & 28 & 30 & 26,00 & 2,86 \\
\hline 5 & 8 & 19 & 21 & 21 & 23 & 24 & 25 & 29 & 23,14 & 2,16 \\
\hline
\end{tabular}

Berdasarkan tabel tersebut menunjukkan bahwa 5 tikus putih pada kelompok perlakuan dengan dosis $1 \mathrm{ml}$ mengalami peningkatan porsi makan selama 7 hari dengan rata-rata $1,90 \mathrm{gr}-2,86 \mathrm{gr}$.

\section{d. Porsi Makan Tikus Putih pada kelompok Perlakuan Dosis 2 ml}

Tabel 1.8 Pengukuran Porsi Makan Tikus Putih pada Kelompok Perlakuan Dosis $2 \mathrm{ml}$ di Laboratorium Farmakologi SMK BIM Pangkalan Bun Tanggal 6-12 Juli 2016

\begin{tabular}{|l|lr|l|l|}
\hline $\begin{array}{l}\text { Samp } \\
\text { el }\end{array}$ & $\begin{array}{l}\text { Pengukuran } \\
\text { Makan }(\text { Gram })\end{array}$ & Porsi & $\begin{array}{l}\text { Rata- } \\
\text { rata }\end{array}$ & Rata-rata \\
peningkat
\end{tabular}




\begin{tabular}{|c|c|c|c|c|c|c|c|c|c|c|}
\hline & \multicolumn{8}{|c|}{ Selama 30 Menit } & \multirow{2}{*}{\multicolumn{2}{|c|}{\begin{tabular}{l|l} 
Porsi an Porsi \\
maka \\
makan \\
hari & (gram) \\
ke-1 & \\
sd & \\
(gra & \\
m) & \\
\end{tabular}}} \\
\hline & \multicolumn{8}{|c|}{ Hari Ke- } & & \\
\hline & 0 & 1 & 2 & 3 & 4 & 5 & 6 & 7 & & \\
\hline \multirow[t]{2}{*}{1} & 7 & 2 & 2 & 2 & 3 & 3 & 3 & 3 & 29,0 & 3,14 \\
\hline & & 1 & 4 & 8 & 1 & 2 & 3 & 4 & 0 & \\
\hline \multirow[t]{2}{*}{2} & 7 & 1 & 2 & 2 & 2 & 2 & 2 & 2 & 23,1 & 2,31 \\
\hline & & 9 & 1 & 1 & 3 & 4 & 5 & 9 & 4 & \\
\hline \multirow[t]{2}{*}{3} & 9 & 1 & 2 & 2 & 2 & 2 & 2 & 2 & 22,2 & 1,90 \\
\hline & & 6 & 0 & 1 & 2 & 4 & 6 & 7 & 9 & \\
\hline \multirow[t]{2}{*}{4} & 1 & 2 & 2 & 2 & 2 & 2 & 2 & 3 & 26,0 & 2,29 \\
\hline & 0 & 1 & 3 & 5 & 7 & 8 & 8 & 0 & 0 & \\
\hline \multirow[t]{2}{*}{5} & 5 & 2 & 2 & 2 & 2 & 2 & 3 & 3 & 26,4 & 3,06 \\
\hline & & 0 & 3 & 5 & 6 & 8 & 1 & 2 & & \\
\hline
\end{tabular}

Berdasarkan tabel di atas menunjukkan bahwa 5 tikus putih pada kelompok perlakuan dengan dosis $2 \mathrm{ml}$ mengalami peningkatan porsi makan selama 7 hari dengan rata-rata $1,90 \mathrm{gr}-3,14 \mathrm{gr}$.

\section{Pengaruh Peningkatan Nafsu Makan Terhadap Berat Badan}

Tabel 1.9 Pengaruh Porsi Makan dengan Berat Badan Tikus Putih di Laboratorium Farmakologi SMK BIM Pangkalan Bun Tanggal 6 - 12 Juli 2016

\begin{tabular}{|c|c|c|c|c|c|c|}
\hline \multirow{3}{*}{$\begin{array}{l}\text { Samp } \\
\text { el }\end{array}$} & \multicolumn{2}{|c|}{$\begin{array}{l}\text { Peningkatan rata- } \\
\text { rata porsi makan } \\
\text { (gr) }\end{array}$} & \multicolumn{4}{|c|}{$\begin{array}{l}\text { Peningkatan rata- } \\
\text { rata berat badan } \\
(\mathrm{gr})\end{array}$} \\
\hline & \multirow{2}{*}{$\begin{array}{l}\text { Kelom } \\
\text { pok } \\
\text { kontrol }\end{array}$} & $\begin{array}{l}\text { Kelompok } \\
\text { perlakuan }\end{array}$ & \multirow{2}{*}{$\begin{array}{l}\text { Kelom } \\
\text { pok } \\
\text { kontrol }\end{array}$} & \multicolumn{3}{|c|}{$\begin{array}{l}\text { Kelompok } \\
\text { Perlakuan }\end{array}$} \\
\hline & & \begin{tabular}{|l|l|l|}
0,5 & 1 & 2 \\
$\mathrm{ml}$ & $\mathrm{ml}$ & $\mathrm{ml}$ \\
\end{tabular} & & & $\begin{array}{l}1 \\
\mathrm{ml}\end{array}$ & 2 \\
\hline \multirow[t]{2}{*}{1} & ,57, & \begin{tabular}{|l|l|l|l|}
2,9 & 1,9 & 3,1 \\
\end{tabular} & 0 , & 3,7 & 1,4 & 1,3 \\
\hline & & 0 & & 1 & & 7 \\
\hline & rot & \begin{tabular}{ll|l}
2,5 & 2,5 & 2,3
\end{tabular} & 0,18 & 1,2 & 1,8 & 1,5 \\
\hline & & 5 & & & & \\
\hline & 36 & \begin{tabular}{|l|l|l|l}
2,5 & 2,8 & 1,9
\end{tabular} & 0,35 & 1,2 & 0,9 & 0,8 \\
\hline & & $1 \quad 2$ & & & & \\
\hline & 67 & \begin{tabular}{|l|l|l|}
2,0 & 2,8 & 2,2
\end{tabular} & 0,55 & 1,0 & 3,0 & 2,0 \\
\hline & & \begin{tabular}{l|l|l}
8 & 6 & 9 \\
\end{tabular} & & & & \\
\hline & 0,51 & \begin{tabular}{|l|l|l|}
2,5 & 2,1 & 3,0 \\
\end{tabular} & 0,37 & 2,5 & 0,6 & 5 \\
\hline
\end{tabular}

\begin{tabular}{|l|l|l|l|l|l|l|l|l|}
\hline & & 5 & 6 & 6 & & 1 & 3 & 3 \\
\hline
\end{tabular}

Berdasarkan tabel 4.9 di atas diketahui bahwa pada kelompok kontrol terjadi peningkatan rata-rata porsi makan maksimal $0,86 \mathrm{gr} / \mathrm{hari}$ dengan peningkatan rata-rata berat badan maksimal $0,55 \mathrm{gr} / \mathrm{hari}$, pada kelompok perlakuan dengan dosis $0,5 \mathrm{ml}$ peningkatan rata-rata porsi makan maksimal mencapai 2,59 gr/hari dengan peningkatan berat badan maksimal 3,71 gr/hari, pada kelompok perlakuan dengan dosis $1 \mathrm{ml}$ peningkatan rata-rata porsi makan maksimal mencapai 2,86 gr/hari dengan peningkatan berat badan maksimal 3,00 gr/hari dan pada kelompok perlakuan dengan dosis $2 \mathrm{ml}$ peningkatan rata-rata porsi makan maksimal mencapai 3,14 gr/hari dengan peningkatan berat badan maksimal 5,33 gr/hari.

Berdasarkan hasil penelitian tersebut dapat disimpulkan bahwa pada kelompok kontrol terjadi peningkatan rata-rata porsi makan yang lambat sehingga peningkatan rata-rata berat badan juga lambat. Sedangkan pada kelompok perlakuan terjadi peningkatan rata-rata porsi makan yang meningkat sehingga peningkatan rata-rata berat badan juga semakin cepat.

\section{A. Analisa Data}

Dengan menggunakan rumus uji T test dua sampel berpasangan yang dihitung dengan SPSS telah didapatkan hasil sebagai berikut :

1. Analisis Berat Badan Tikus Putih

Tabel 1.10 Hasil Uji T Test Dua Sampel Berpasangan Pengaruh Buah Tomat (Solanum Lycopersicum) terhadap Berat Badan pada Tikus Putih (Ratus Novergicus Stain Wistar) di Laboratorium Farmakologi SMK BIM Pangkalan Bun.

\begin{tabular}{|l|l|l|l|}
\hline Variabel & Sampel & $\alpha$ & $\begin{array}{l}\text { Nilai } \\
\text { Signifikan } \\
(\rho)\end{array}$ \\
\hline
\end{tabular}




\begin{tabular}{|l|l|l|l|}
\hline $\begin{array}{l}\text { Skor rata- } \\
\text { rata berat }\end{array}$ & & & \\
badan & 20 & 0,05 & .002 \\
kelompok & & & \\
kontrol \& & & & \\
$\begin{array}{l}\text { Skor rata- } \\
\text { rata berat }\end{array}$ & & & \\
badan ran & & & \\
kelompok & & & \\
perlakuan & & & \\
\hline
\end{tabular}

Berdasarkan tabel analisis berat badan tikus diketahui hasil analisa data menggunakan uji-T sampel berpasangan pada berat badan tikus putih kelompok kontrol dan kelompok perlakuan didapatkan hasil nilai sig (2tailed) $\rho: 0,002$ dan taraf kesalahan $(\alpha)$ : 0,05 , jadi $\rho<\alpha$ sehingga $\mathrm{H}_{0}$ ditolak dan $\mathrm{H}_{1}$ diterima, artinya ada pengaruh buah tomat (solanum lycopersicum) terhadap berat badan pada tikus putih (ratus novergicus stain wistar) di Laboratorium Farmakologi Universitas Brawijaya Malang. Nilai Uji T sampel berpasangan sebesar 5,97 s/d 44,82 artinya kekuatan pengaruh 95\%. Hasil analisa adalah positif artinya semakin sering anak mengkonsumsi buah tomat maka nafsu makan juga akan meningkat ditandai dengan berat badan yang meningat pula, begitu juga sebaliknya jika tidak pernah mengkonsumsi buah tomat maka anak dapat mengalami kekurangan nafsu makan ditandai dengan berat badan yang kurang meningkat.

\section{Analisis Porsi Makan Tikus Putih}

Tabel 1.11 Hasil Uji T Test Dua Sampel Berpasangan Pengaruh Buah Tomat (Solanum Lycopersicum) terhadap Porsi Makan pada Tikus Putih (Ratus Novergicus Stain Wistar) di Laboratorium Farmakologi SMK BIM Pangkalan Bun

\begin{tabular}{|l|l|l|l|}
\hline Variabel & Sampel & $\alpha$ & $\begin{array}{l}\text { Nilai } \\
\text { Signifikan } \\
(\rho)\end{array}$ \\
\hline $\begin{array}{l}\text { Skor rata-rata } \\
\text { porsi makan } \\
\text { kelompok }\end{array}$ & 20 & 0,05 & .000 \\
\hline
\end{tabular}

\begin{tabular}{|l|l|l|l|}
\hline kontrol \& Skor & & & \\
rata-rata porsi & & & \\
makan & & & \\
kelompok & & & \\
perlakuan & & & \\
\hline
\end{tabular}

Berdasarkan analisis porsi makan diketahui hasil analisa data menggunakan uji-T sampel berpasangan pada berat badan tikus putih kelompok kontrol dan kelompok perlakuan didapatkan hasil nilai sig (2tailed) $\rho: 0,000$ dan $\alpha: 0,05$, jadi $\rho<\alpha$ sehingga $\mathrm{H}_{0}$ ditolak dan $\mathrm{H}_{1}$ diterima, artinya ada pengaruh buah tomat (solanum lycopersicum) terhadap porsi makan pada tikus putih (ratus novergicus stain wistar) di Laboratorium Farmakologi SMK BIM Pangkalan Bun. Nilai Uji T sampel beerpasangan sebesar 18,9 s/d 25,9 artinya kekuatan pengaruh $95 \%$. Hasil analisa adalah positif artinya semakin sering anak mengkonsumsi buah tomat maka nafsu makan juga akan meningkat ditandai dengan porsi makan yang meningat pula, begitu juga sebaliknya jika tidak pernah mengkonsumsi buah tomat maka anak dapat mengalami kekurangan nafsu makan ditandai dengan pengurangan porsi makan.

\section{PEMBAHASAN}

\section{Identifikasi Berat Badan dan Pola Makan Tikus Putih (Ratus Novergicus Stain Wistar) pada Kelompok Kontrol.}

Berdasarkan hasil penelitian menunjukkan bahwa 5 tikus putih pada kelompok kontrol mengalami peningkatan berat badan selama 7 hari dengan rata-rata 0,12 gr $-0,37$ gr sedangkan untuk peningkatan porsi makan dengan rata-rata $0,04 \mathrm{gr}-0,86 \mathrm{gr}$.

Gangguan nafsu makan merupakan gangguan klinis yang penting namun sering kali diabaikan (Grilo dan Mitchell, 2010). Masalah ini sebenarnya merupakan hal yang sepele namun sering menjadi masalah utama terutama pada anak-anak (Manikam dan Perman, 2010). Menurut Waugh dan Lask (2010), 25\%-45\% anak yang berkembang 
normal mengalami gangguan nafsu makan sedangkan pada anak yang terlambat perkembangannya angka ini mencapai $80 \%$. Jika gangguan ini tidak segera diatasi maka dapat menimbulkan masalah yang serius. Salah satu masalah yang ditimbulkan akibat kurangnya nafsu makan adalah gagalnya pemenuhan kebutuhan nutrisi. Jika hal ini dibiarkan berkepanjangan maka dapat mengakibatkan gangguan kesehatan dan perkembangan anak. Kerja normal berbagai organ juga sangat terganggu apabila terjadi defisiensi nutrisi. Selain itu, nafsu makan erat kaitannya dengan berat badan. Kebanyakan penderita gangguan nafsu makan juga diikuti dengan penurunan berat badan yang cukup drastis sehingga memiliki berat badan dibawah normal. Tidak idealnya berat badan anak ini dapat mengakibatkan berbagai masalah.

Pengaruh hilang atau berkurangnya nafsu makan tampaknya merupakan penyebab utama masalah kesulitan makan pada anak. Pengaruh nafsu makan ini bisa mulai dari yang ringan (berkurang nafsu makan) hingga berat (tidak ada nafsu makan). Tampilan gangguan yang ringan berupa minum susu botol sering sisa, waktu minum ASI berkurang (sebelumnya 20 menit menjadi 10 menit), makan sering sisa atau hanya sedikit atau mengeluarkan dan menyembur-nyemburkan makanan di mulut. Sedangkan gangguan yang lebih berat tampak anak menutup rapat mulutnya atau tidak mau makan dan minum sama sekali (Judarwanto, 2014: 64).

Menurut peneliti, kurangnya nafsu makan anak dapat mengakibatkan tidak idealnya berat badan anak. Dalam jangka panjang, gangguan nafsu makan ini juga dapat mengancam jiwa. Gangguan ini sukar diatasi selain karena sukar untuk didiagnosa penyebabnya, juga tidak adanya obat konvensional yang berkerja langsung untuk meningkatkan nafsu makan. Kurangnya nafsu makan akan berpengruh pada tumbuh kembang. Berkurangnya nafsu makan anak makin meningkat berkaitan dengan makin meningkatnya interaksi dengan lingkungan, mereka lebih mudah terkena penyakit terutama penyakit infeksi baik yang akut maupun yang menahun, infeksi cacing dan sebagainya. Pada usia 4-5 tahun berkurangnya nafsu makan di samping karena sakit juga oleh karena faktor lain misalnya waktu/kesempatan untuk makan karena kesibukan bermain.

\section{Identifikasi Berat Badan dan Pola Makan Tikus Putih (Ratus Novergicus Stain Wistar) pada Kelompok Perlakuan.}

Berdasarkan hasil penelitian menunjukkan bahwa 5 tikus putih pada kelompok perlakuan dengan dosis $0,5 \mathrm{ml}$ mengalami peningkatan berat badan selama 7 hari dengan rata-rata $1,08 \mathrm{gr}-3,71 \mathrm{gr}$, kelompok perlakuan dengan dosis $1 \mathrm{ml}$ mengalami peningkatan berat badan rata-rata $0,63 \mathrm{gr}-$ 3,00 gr dan pada kelompok perlakuan dengan dosis $2 \mathrm{ml}$ mengalami peningkatan berat badan rata-rata 0,80 gr $-5,33$ gr. Sedangkan untuk porsi makan menunjukkan bahwa 5 tikus putih pada kelompok kontrol mengalami peningkatan porsi makan selama 7 hari dengan rata-rata $0,04 \mathrm{gr}-0,86 \mathrm{gr}$, kelompok perlakuan dengan dosis $0,5 \mathrm{ml}$ mengalami peningkatan porsi makan ratarata 2,08 gr - 2,92 gr, kelompok perlakuan dengan dosis $1 \mathrm{ml}$ mengalami peningkatan porsi makan rata-rata $1,90 \mathrm{gr}-2,86 \mathrm{gr}$ dan kelompok perlakuan dengan dosis $2 \mathrm{ml}$ mengalami peningkatan porsi makan ratarata $1,90 \mathrm{gr}-3,14 \mathrm{gr}$.

Kesulitan makan yang berat dan berlangsung lama akan berdampak pada kesehatan dan tumbuh kembang anak. Gejala yang timbul tergantung dari jenis dan jumlah zat gizi yang kurang. Bila anak hanya tidak menyukai makanan tertentu misalnya buah atau sayur akan terjadi defisiensi vitamin A. Bila hanya mau minum susu saja akan terjadi anemi defisiensi besi. Bila kekurangan kalori dan protein akan terjadi kekurangan energi protein (KEP). Kesulitan makan merupakan 
gejala ketidak mampuan secara wajar dalam memenuhi kebutuhan zat gizi. Penyebab kesulitan makan mungkin suatu penyakit tetapi mungkin juga banyak faktor yang terlibat. Perlu dilakukan upaya gizi yang sesuai untuk memperbaiki dampak kesulitan makan terhadap gangguan tumbuh kembang dan gangguan gizi. Perlu dilakukan upaya melenyapkan/mengobati penyebabnya. Mungkin diperlukan pendekatan multi disiplin.

Tomat (Solanum lycopersicum syn. Lycopersicum) adalah tumbuhan dari keluarga Solanaceae, tumbuhan asli Amerika Tengah dan Selatan, dari Meksiko sampai Peru. Tomat merupakan tumbuhan siklus hidup singkat, dapat tumbuh tinggi setinggi 1-3 m. Tomat merupakan keluarga dekat dari kentang (Fakriana, 2014: 62).

Tomat mengandung alkaloid slonain $(0,007 \%)$, saponin, asam folat, asam malat, asam sitrat, bioflavonoid, protein, lemak, gula (glukosa dan fruktosa), adenine, trigonelin, kholin, tomatin, mineral $(\mathrm{Ca}, \mathrm{Mg}$, $\mathrm{P}, \mathrm{K}, \mathrm{Na}, \mathrm{Fe}$, Sulfur, chlorine), vitamin (B1, B2, B6, C, E, A, Likopen, niasin), karbohidrat, histamine, serat, Zat Fitonutrien. Sari buah tomat mengandung vitamin dan mineral yang cukup lengkap. Dari 100 gram jus tomat akan diperoleh kalsium $7 \mathrm{mg}$, fosfor $15 \mathrm{mg}$,zat besi $0,9 \mathrm{mg}$, natrium $230 \mathrm{mg}$, dan kalium $230 \mathrm{mg}$. Vitamin yang terdapat dalam 100 gram sari buah tomat adalah vitamin A (1.050 IU), vitamin B1 (0.05 mg), vitamin B2 (0,03 mg) dan vitamin $\mathrm{C}$ (16 mg). Tomat memiliki rasa yang sedikit asam membuat selera makan meningkat. Rasa asam buah tomat berasal dari asam sitrat. Berkhasiat menambah nafsu makan dengan cara memperbanyak keluarnya air liur. Berdasarkan penelitian bahan bahan yang dikandung di dalam tomat memiliki manfaat salah satunya untuk meningkatkan nafsu makan. Rasa asam pada tomat berasal dari kandungan asam sitrat menyebabkan tomat terasa segar, sehingga dapat menambah nafsu makan. Tomat kaya garam mineral yang merangsang aliran air liur. Mineral ini berguna merangsang nafsu makan sekaligus membuat makanan mudah dicerna tubuh. Konsumsi tomat teratur membantu mengobati penyakit anoreksia (kehilangan nafsu makan).

Menurut peneliti, buah tomat bisa dikatakan buah yang banyak mengandung serat sehingga baik untuk dikonsumsi terutama pada anak-anak. Minum Jus tomat satu jam sebelum makan mampu meningkatkan nafsu makan. Tomat tua dan masak alami selalu berbau alkalin dan rasanya sedikit masam, Itu karena tomat memiliki garam mineral. Mineral-mineral itulah yang merangsang aliran air liur, sehingga menambah rasa lapar. Meningkatnya nafsu makan anak akan berpengaruh pada tumbuh kembang anak sendiri, dimana dengan pepenuhan nutrisi yang baik maka tumbuh kembang anak akan ideal dan sesuai dengan umur, sehingga diharapkan akan meningkatkan generasi bangsa yang tangguh dan sehat.

\section{Pengaruh Buah Tomat (Solanum Lycopersicum) terhadap Nafsu Makan pada Tikus Putih (Ratus Novergicus Stain Wistar)}

Berdasarkan hasil analisa data mengenai berat badan tikus putih pada kelompok kontrol dan perlakuan menggunakan uji-T sampel berpasangan pada berat badan tikus putih kelompok kontrol dan kelompok perlakuan didapatkan hasil nilai sig (2tailed) $\rho: 0,002$ dan $\alpha: 0,05$, jadi $\rho<\alpha$ sehingga $\mathrm{H}_{0}$ ditolak dan $\mathrm{H}_{1}$ diterima, artinya ada pengaruh buah tomat (solanum lycopersicum) terhadap berat badan pada tikus putih (ratus novergicus stain wistar). Sedangkan untuk porsi makan diketahui bahwa hasil analisa data mengenai porsi makan tikus putih pada kelompok kontrol dan perlakuan menggunakan uji-T sampel berpasangan pada berat badan tikus putih kelompok kontrol dan kelompok perlakuan didapatkan hasil nilai sig (2-tailed) $\rho: 0,000$ dan $\alpha$ : 0,05 , jadi $\rho<\alpha$ sehingga $\mathrm{H}_{0}$ ditolak dan $\mathrm{H}_{1}$ diterima, artinya ada pengaruh buah tomat (solanum lycopersicum) terhadap 
porsi makan pada tikus putih (ratus novergicus stain wistar) di Laboratorium Farmakologi SMK BIM Pangkalan Bun.

Tikus putih atau mencit adalah binatang asli Asia, India dan Eropa Barat. Jenis ini sekarang ditemukan di seluruh dunia karena pengenalan oleh manusia (Sari, 2012: 22). Tikus adalah binatang yang hidup bersama, tinggal di dalam selama cuaca dingin dan bergerak di luar selama musim semi dan musim panas, bentuk-bentuk liar, tinggal di luar sepanjang hidup mereka, dan dikurung binatang, terus untuk penelitian, pengujian, mengajar, hewan peliharaan dan mewah (Isroi, 2010: 23).

Tomat (Solanum lycopersicum) ada dua macam yaitu tomat buah dan tomat sayur. Perbedaannya terletak pada bentuk dan ketebalan kulitnya. Kalau tomat buah, bentuknya agak lonjong dan kulitnya tebal. Sebaliknya, tomat sayur berbentuk bulat dan kulitnya lebih tipis. Tomat buah biasanya digunakan sebagai salad segar, dan langsung dikonsumsi tanpa perlu dimasak terlebih dahulu. Tomat jenis ini lebih tahan lama dibandingkan tomat sayur. Tomat sayur biasanya digunakan sebagai campuran sayur yang dimasak, dan tidak bisa tahan lama (Restu, 2011: 22).

Rasa asam dalam buah tomat berasal dari kandungan asam sitrat menyebabkan tomat terasa segar, sehingga dapat menambah nafsu makan. Tomat kaya akan garam mineral yang merangsang aliran air liur. Mineral ini berguna merangsang nafsu makan sekaligus membuat makanan dicerna tubuh,serta menambah rasa lapar sekaligus memungkinkan makanan dicerna dengan baik (Dewi, 2012: 40-42).

Dorongan untuk makan dipengaruhi oleh rasa lapar dan nafsu makan. Nafsu makan merupakan suatu keadaan yang mendorong seseorang untuk memuaskan keinginan makan. Nafsu makan diregulasi oleh hipotalamus terutama pada hipotalamus lateral serta nuklei ventro medialis.
Rangsangan terhadap hipotalamus lateral akan mengakibatkan meningkatnya nafsu makan sedangkan rangsangan terhadap nuklei ventro medialis akan berefek sebaliknya. Jika dilihat dari segi gizi anak, makan merupakan upaya untuk memenuhi kebutuhan individu terhadap berbagai macam zat gizi (nutrien) untuk berbagai keperluan metabolisme berkaitan dengan kebutuhan untuk mempertahankan hidup, mempertahankan kesehatan dan untuk pertumbuhan dan perkembangan.

Makan merupakan pendidikan agar anak terbiasa kebiasaan makan yang baik dan benar dan juga untuk mendapatkan kepuasan dan kenikmatan bagi anak maupun bagi pemberinya terutama ibu. Bagi anak makan merupakan perilaku yang kompleks dengan keterampilan yang harus dipelajari secara bertahap. Nafsu makan erat kaitannya dengan berat badan. Kebanyakan penderita gangguan nafsu makan juga diikuti dengan penurunan berat badan yang cukup drastis sehingga memiliki berat badan dibawah normal. Ketidakidealan berat badan anak ini dapat mengakibatkan berbagai masalah. Apabila gangguan nutrisi ini berlangsung dalam jangka waktu yang panjang maka dapat menyebabkan berbagai masalah kesehatan. Selain keterkaitannya dengan kebutuhan nutrisi, nafsu makan juga erat kaitannyadengan berat badan. Kurangnya nafsu makan anak dapat mengakibatkan tidak idealnya berat badan anak. Dalam jangka panjang, gangguan nafsu makan ini juga dapat mengancam jiwa. Gangguan ini sukar diatasi selain karena sukar untuk didiagnosa penyebabnya, juga tidak adanya obat konvensional yang berkerja langsung untuk meningkatkan nafsu makan melainkan berasal dari efek samping dari obat tersebut

Menurut peneliti buah tomat merupakan buah yang banyak mengandung manfaat bagi manusia salah satunya adalah untuk meningkatkan nafsu makan. Tomat memiliki rasa yang sedikit asam membuat selera makan meningkat. Rasa asam buah tomat berasal dari asam sitrat. Berkhasiat 
menambah nafsu makan dengan cara memperbanyak keluarnya air liur. Berdasarkan penelitian bahan bahan yang dikandung di dalam tomat memiliki manfaat salah satunya untuk meningkatkan nafsu makan. Rasa asam pada tomat berasal dari kandungan asam sitrat menyebabkan tomat terasa segar, sehingga dapat menambah nafsu makan. Tomat kaya garam mineral yang merangsang aliran air liur. Mineral ini berguna merangsang nafsu makan sekaligus membuat makanan mudah dicerna tubuh. Konsumsi tomat teratur membantu mengobati penyakit anoreksia (kehilangan nafsu makan). Olahan tomat terbaik adalah berupa jus. Minum Jus tomat satu jam sebelum makan mampu meningkatkan nafsu makan. Tomat tua dan masak alami selalu berbau alkalin dan rasanya sedikit masam, Itu karena tomat memiliki garam mineral. Mineral-mineral itulah yang merangsang aliran air liur, sehingga menambah rasa lapar sekaligus memungkinkan makanan dicerna baik.

\section{SIMPULAN DAN SARAN}

\section{Simpulan}

Berdasarkan penyajian data dan hasil analisis data tentang pengaruh buah tomat (solanum lycopersicum) terhadap peningkatan nafsu makan pada tikus putih (ratus novergicus stain wistar) di Laboratorium Farmakologi SMK BIM Pangkalan Bun maka dapat disimpulkan sebagai berikut :

1. Peningkatan berat badan dan porsi makan pada kelompok kontrol menunjukkan bahwa 5 tikus putih mengalami peningkatan berat badan selama 7 hari dengan rata-rata 0,12 gr $-0,37$ gr sedangkan untuk peningkatan porsi makan dengan rata-rata $0,04 \mathrm{gr}-0,86 \mathrm{gr}$.

2. Peningkatan berat badan dan porsi makan pada kelompok perlakuan selama 7 hari menunjukkan bahwa 5 tikus putih dengan dosis $0,5 \mathrm{ml}$ mengalami peningkatan berat badan rata-rata $1,08 \mathrm{gr}-3,71 \mathrm{gr}$, dosis $1 \mathrm{ml}$ peningkatan berat badan ratarata $0,63 \mathrm{gr}-3,00 \mathrm{gr}$ dan dosis $2 \mathrm{ml}$ mengalami peningkatan berat badan ratarata $0,80 \mathrm{gr}-5,33$ gr. Sedangkan untuk porsi makan menunjukkan bahwa 5 tikus putih mengalami peningkatan porsi makan rata-rata 0,04 gr $-0,86$ gr, dosis $0,5 \mathrm{ml}$ peningkatan porsi makan rata-rata $2,08 \mathrm{gr}-2,92 \mathrm{gr}$, dosis $1 \mathrm{ml}$ mengalami peningkatan porsi makan rata-rata 1,90 gr - 2,86 gr dan dosis $2 \mathrm{ml}$ mengalami peningkatan porsi makan rata-rata $1,90 \mathrm{gr}$ $-3,14$ gr.

3. Hasil analisa data mengenai berat badan tikus putih didapatkan hasil nilai sig (2tailed) $\rho: 0,002$ dan $\alpha: 0,05$, jadi $\rho<\alpha$ sehingga $\mathrm{H}_{0}$ ditolak dan $\mathrm{H}_{1}$ diterima, artinya ada pengaruh buah tomat (solanum lycopersicum) terhadap berat badan pada tikus putih (ratus novergicus stain wistar). Sedangkan hasil analisa data mengenai porsi makan tikus putih didapatkan hasil nilai sig (2-tailed) $\rho$ : 0,000 dan $\alpha$ : 0,05, jadi $\rho<\alpha$ sehingga $\mathrm{H}_{0}$ ditolak dan $\mathrm{H}_{1}$ diterima, artinya ada pengaruh buah tomat (solanum lycopersicum) terhadap porsi makan pada tikus putih (ratus novergicus stain wistar) di Laboratorium Farmakologi SMK BIM Pangkalan Bun.

\section{Saran}

\section{Bagi Masyarakat}

Diharapkan hasil penelitian yang dilakukan di laboratorium farmakologi SMK BIM Pangkalan Bun ini dapat memberikan informasi kepada masyarakat tentang pentingnya meningkatkan nafsu makan anak untuk memenuhi kebutuhan gizi anak setiap hari terutama pada anak yang mengalami masalah nafsu makan dengan memberikan alternatif pilihan secara mudah dan murah. Pada masyarakat terutama yang mempunyai anak usia pra sekolah untuk memberikan buah tomat setiap hari untuk meningkatkan 
nafsu makan anak sehingga tumbuh kembang anak dapat berkembang dengan baik.

\section{Bagi Pemegang Program Gizi}

Hasil penelitian yang dilakukan di laboratorium farmakologi SMK BIM Pangkalan Bun ini diharapkan dapat memberikan informasi kepada pemegang program gizi untuk meningkatkan pelayanan kepada masyarakat guna tercapainya pemenuhan gizi yang baik sehingga pemenuhan gizi anak dapat terpenuhi setiap hari secara seimbang dengan memberikan alternatif pilihan secara mudah dan murah. Salah satu cara pelayanannya adalah dengan memberikan penyuluhan di desa-desa mengenai pentingnya peningkatan nafsu makan anak terutama pada anak usia pra sekolah.

\section{Bagi Guru TK}

Diharapkan penelitian yang dilakukan di laboratorium farmakologi SMK BIM Pangkalan Bun ini dapat diterapkan oleh para guru TK dengan memberikan pengertian kepada anak didik tentang pentingnya buah tomat sehingga dapat mengatasi permasalahan nafsu makan anak yang berkurang dengan memberikan alternatif pilihan secara mudah dan murah. Bagi guru TK bisa memberikan jus tomat minimal 1 minggu sekali sehingga diharapkan dapat meningkatkan nafsu mkan anak sehingga masalah tumbuh kembang anak dapat teratasi.

\section{Bagi Peneliti}

Diharapkan hasil penelitian yang dilakukan di laboratorium farmakologi SMK BIM Pangkalan Bun ini dapat menambah pengetahuan dan ketrampilan peneliti tentang pengaruh pemberian buah tomat terhadap peningkatan nafsu makan sehingga setelah terjun di masyarakat dikemudian hari dapat diterapkan secara langsung.

5. Bagi Peneliti Selanjutnya
Hasil penelitian yang dilakukan di laboratorium farmakologi SMK BIM Pangkalan Bun ini diharapkan dapat memberikan manfaat sebagai acuan peneliti selanjutnya dan menambah variabel pada peneliti selanjutnya tentang pengaruh buah tomat terhadap peningkatan nafsu makan tikus putih (ratus novergicus stain wistar).

\section{DAFTAR PUSTAKA}

Agusman. 2012. Upaya Dietetik Dalam Mengatasi Kesulitan Makan Pada Anak. Dalam Samsudin dan Aryatmo Tjokronegoro, Eds. Gizi dan Tumbuh Kembang. Jakarta: Balai penerbit FKUI.

Arikunto. 2011. Prosedur Penelitian Suatu Pendekatan Praktik. Jakarta: Rineka Cipta.

Aviram, M., Dornfeld, L., Rosenblat, M., Volkova, N., Kaplan, M., Coleman, R., Hayek, T., Presser, D., dan Fuhrman, B.S 2010. Pomegranate Juice Consumption Reduces Oxidative Stress, Atherogenic Modifications to LDL, and Platelet Aggregation : Studies in Human and in Atherosclerotic Apolipoprotein Edeficient Mice. Available from : http://www.ajcn.org.

Dewi. 2012. Khasiat dan Manfaat Tomat. Surabaya: Stomata.

Fakriana.2014.Buah dan sayur. Magelang: Azka Pustaka.

Gunarso. 2011. Anoreksia pada Anak: Aspek Psikologis. Dalam Naskah Lengkap Pendidikan Kedokteran Berkelanjutan Ilmu Kesehatan Anak ke XXXI. Jakarta, Universitas Indonesia.

Grilo dan Mitchell. 2010. The treatment of Eating Disorders: A Clinical 
Handbook. New York: The Guildford Press.

Isroi. 2010. Pemberian Ekstrak Kulit Terung Ungu-Antosianin (Solanum melongena L.) Menurunkan MDA Dalam Darah Tikus Wistar (Rattus norvegicus) yang Diinduksi Aktivitas Fisik Maksimal. (Tesis). Program Pasca Sarjana Ilmu Biomedik Universitas Udayana.

Judarwanto. 2014. Mengatasi Kesulitan Makan Anak. Jakarta : Puspaswara Publisher.

Manikam dan Perman. 2010. Pediatric Feeding Disorder. Journal of Clin Gastroenterol.

Ngatidjan. 2010. Metode Laboratorium Dalam Toksikologi. Metode Uji Toksisitas.

Notoatmodjo. 2010. Metodologi Penelitian Kesehatan. Jakarta: Rineka Cipta.

Nursalam. 2011. Penerapan Metodologi Penelitian Ilmu Keperawatan. Jakarta: Salemba Medika.

Nursalam. 2014. Metode Penelitian Ilmu Keperawatan. Jakarta: Salemba Medika.

Restu. 2011. Tomat, Usaha Tani dan Penanganan Pasca Panen. Yogyakarta: Kanisius.
Riskesdas. 2013. Riset Kesehatan Dasar. Jakarta: Badan Penelitian dan Perkembangan Kesehatan. Kementerian Kesehatan RI.

Samsudin. 2011. Penggunaan Rasional Prepovat Vitamin Mineral dan Merangsang Nafsu Makan. Dalam : Sri Nasar dan Sukarti Agusman eds. Berbagai Aspek tentang Vitamin dan Mineral pada Tumbuh Kembang Anak. Jakarta: Balai Penerbit FKUI.

Santoso. 2012. Kesehatan dan Gizi. Jakarta: Rineka Cipta.

Sari. 2012. Pelatihan Fisik Berlebih Menurunkan Konsentrasi dan Motilitas Spermatozoa Tikus Putih (Tesis). Denpasar: Universitas Udayana.

Sugiyono. 2010. Statistika Nonparametris. Bandung : Alvabeta.

Sunarjo. 2013. Kesulitan Makan Pada Anak. Dalam Makalah Lengkap Pendidikan Kedokteran Berkelanjutan Ilmu Kesehatan Anak ke XXXI. Jakarta, Universitas Indonesia

Waugh dan Lask. 2010. Treatment of Childhood Eating Difficulties and Disorder, The Treatment of Eating Disorders.

Widodo. 2013. Pemberian Makanan, Suplemen dan Obat pada Anak. Jakarta: EGC. 